\title{
MINIATURIZED LIQUID-LIQUID EXTRACTION WITH LOW-TEMPERATURE PARTITIONING TECHNIQUE (LLE/LTP) FOR PESTICIDE ANALYSIS IN A BIOLOGICAL MATRIX BY GAS CHROMATOGRAPHY
}

\author{
Thaís Lindenberg R. Silva ${ }^{a}$, Maria Eliana L. R. de Queiroz ${ }^{\mathrm{a}, *,(}$, Antônio A. Neves ${ }^{\mathrm{a}}$, Patrícia Aparecida F. Vieira ${ }^{\mathrm{b}}$, André F. \\ de Oliveira $^{a}$ and Maria Goreti de A. Oliveira ${ }^{c}$ \\ aDepartamento de Química, Universidade Federal de Viçosa, 36570-900 Viçosa - MG, Brasil \\ 'Departamento de Nutrição, Universidade Federal de Viçosa, 36570-900 Viçosa - MG, Brasil \\ 'Departamento de Bioquímica e Biologia Molecular, Universidade Federal de Viçosa, 36570-900 Viçosa - MG, Brasil
}

Recebido em 06/11/2020; aceito em 23/02/2021; publicado na web em 23/03/2021

\begin{abstract}
The liquid-liquid extraction with low-temperature partitioning technique (LLE/LTP) was miniaturized to determine the pesticides chlorpyrifos, bifenthrin, $\lambda$-cyhalothrin, and deltamethrin in a biological matrix, by gas chromatography. The method was proposed for fetal-bovine serum samples $(500 \mu \mathrm{L})$, by using a full factorial design $\left(2^{3}\right)$ with one center point. The evaluated factors included the volume of water added to the sample $(1000 \mu \mathrm{L})$, volume of extraction solvent $(500 \mu \mathrm{L})$ and stirring time $(60 \mathrm{~s})$ - a cleanup step was not necessary. The method was validated for the main figures of merit. The results indicated that the LLE/LTP/GC/ECD miniaturized method was efficient in extracting pesticides from blood-serum samples ( 75 to $115 \%$ ). It showed both selectivity and sensitiveness, with limits of quantification (LOQ) ranging from 8 at $17 \mu \mathrm{g} \mathrm{L}^{-1}$. Once validated, the method was applied to blood-serum samples of rural workers from a city in the Brazilian state of Minas Gerais. In that case, the presence of chlorpyrifos was detected in two of the samples.
\end{abstract}

Keywords: method development; pesticides; blood-serum.

\section{INTRODUCTION}

The indiscriminate use of agricultural pesticides has caused several foodstuffs to get contaminated. This problem is mainly linked to the employment of pesticides not allowed for a specific culture, or because their application does not abide by the good agricultural practices. ${ }^{1}$

Currently, pesticide exposure has been associated with some severe health conditions, such as cancer ${ }^{2,3}$ and Parkinson's disease. ${ }^{4}$ Rural workers and agrochemical retailers are in continuous contact with these substances, thus being the ones more likely to being contaminated. ${ }^{5,6}$ On account of that problematic, researchers have investigated the contamination process ${ }^{7,8}$ and the risks that pesticides pose to human health. ${ }^{5-9}$ In this context, toxicological analyses are crucial tools, as they determine and quantify exogen substances (pesticides) in biological tissues and fluids. ${ }^{10}$

Blood is one of the matrices that can be used in these tests. It is a complex fluid composed of water, soluble proteins, lipids, salts, and cells. The contamination can be assessed in terms of whole blood, plasma, or serum - the last two are the supernatants obtained after blood centrifugation, and they differ as for the existence of fibrinogens or lack thereof. ${ }^{11}$ Some studies have successfully used blood serum to monitor pesticides in humans. ${ }^{12-14}$

When monitoring pesticide contamination in individuals, the sample complexity is a limiting factor. It is imperative to develop methods that reliably determine the compounds of interest and remove any substances that might cause interference with the analyte signal, or which are not compatible with the technique adopted. Blood proteins, for example, are incompatible with gas chromatographic columns. ${ }^{15}$ Another curbing aspect is the sample size, as traditional extraction techniques, such as the solid-phase extraction (SPE) $)^{16,17}$ and the QuEChERS require large samples volumes. ${ }^{18}$

A technique that has shown promising results in different

*e-mail: meliana@ufv.br complex matrices, including the biological ones, is the liquid-liquid extraction with low-temperature partitioning (LLE/LTP). In general, this technique has the advantage of promoting both the extraction and cleanup in a single step, without requiring an additional procedure for precipitating proteins - as occurs in other well-established methodologies that make use of solid-phase (SPE) or liquid-liquid (LLE) extractions. ${ }^{19,20}$ In biological samples, the extraction with low-temperature partitioning was successfully used to determine benzodiazepines and benzene metabolites in human urine, ${ }^{21,22}$ and cocaine in human liver. ${ }^{23}$

The objective of this research was to miniaturize the LLE/LTP technique, to reduce both the size of the blood serum sample and the volume of organic solvents required to determine pesticide residues. The proposed method was validated and applied to monitor the pesticide contamination in blood samples of rural workers.

\section{MATERIAL AND METHODS}

\section{Reagents and solutions}

The experiments used $99.5 \%$ acetonitrile, HPLC grade (SigmaAldrich, USA), and the pesticide standards chlorpyrifos $(99.0 \% \mathrm{w} / \mathrm{w})$, $\lambda$-cyhalothrin $(86.5 \% \mathrm{w} / \mathrm{w})$, deltamethrin $(99 \% \mathrm{w} / \mathrm{w})$ (Syngenta, Brazil), and bifenthrin $(92.2 \% \mathrm{w} / \mathrm{w})$ (FMC, Brazil). Table $1 \mathrm{~S}$ presents the analytes under study and relates them to their chemical structures, physical-chemical and toxicological properties. Stock solutions of the analytes were prepared at the concentration of $1000 \mathrm{mg} \mathrm{L}^{-1}$, having acetonitrile as solvent. These solutions were the basis to preparing mixtures at different concentrations, which were used in the tests.

The samples consisted of fetal-bovine serum (Cultilab, Brazil), which was inactive, sterile, and mycoplasma-free, to optimize and validate the extraction method. The choice of this matrix took into account its similarity with the human counterpart and the possibility of reducing sampling in humans, thus avoiding risks for the volunteer donor and the analyst. 


\section{Equipment}

The chromatographic analyzes were performed with a gas chromatograph (GC) model GC-2014, equipped with an electron capture detector (ECD) (Shimadzu, Japan), or a gas chromatograph model 7820A GC, coupled to a mass spectrometer (MS) model 5977B MDS (Agilent, USA). In both cases, HP-5MS fused-silica capillary columns ( $30 \mathrm{~m} \times 0.25 \mathrm{~mm} \times 0.25 \mu \mathrm{m}$ film thickness) were employed (Hexis, Brazil). Nitrogen or helium was used as the carrier gas in the GC/ECD and GC-MS, respectively.

To separate the analytes of interest, the column was initially set to $150{ }^{\circ} \mathrm{C}$, and kept so for $1 \mathrm{~min}$. After that, the column was heated at a $30{ }^{\circ} \mathrm{C} \mathrm{min}{ }^{-1}$ rate until $210{ }^{\circ} \mathrm{C}$, staying in this condition for another minute. Subsequently, the column was heated at $30{ }^{\circ} \mathrm{C} \mathrm{min}{ }^{-1}$ until $250{ }^{\circ} \mathrm{C}$, and then at $20{ }^{\circ} \mathrm{C} \mathrm{min}^{-1}$ until $290{ }^{\circ} \mathrm{C}$, temperature at which it remained for $2 \mathrm{~min}$. The total analysis time amounted to $11.3 \mathrm{~min}$. In both devices, the injectors and detectors were maintained at $300{ }^{\circ} \mathrm{C}$.

The sample was input to the GC/ECD at a 1:5 split ration, whereas a splitless injection was adopted for the GC-MS. In both cases, however, the sample volume was the same $(1 \mu \mathrm{L})$. The temperatures of the detector interface and the ionization source were set at $300{ }^{\circ} \mathrm{C}$ and $200{ }^{\circ} \mathrm{C}$, respectively. The full scan (TIC or Scan) and selectedion monitoring (SIM) acquisition modes were applied during the chromatographic run. Lastly, other equipment utilized included a CERTOMAT $^{\circledR}$ MV vortex mixer (B. BRAUN INTERNACIONAL, Germany) and a 280-liter CVU30D freezer (CONSUL, Brazil).

\section{Screening of critical conditions of the LLE/LTP/GC method}

The screening of critical conditions of the LLE/LTP/GC method followed a full factorial design $2^{3}$, with one center point $(n=2)$. For this purpose, ten trials were carried out, in which the variables volume of added water $(700-1000 \mu \mathrm{L})$, the volume of extracting solvent $(500-700 \mu \mathrm{L})$, and stirring time $(20-60 \mathrm{~s})$ were appraised. The concentrations obtained from the chromatographic runs of the extracts were used as analytical responses. The concentrations were obtained from calibration curves constructed for each pesticide in acetonitrile. Solutions with concentrations close to those expected in the tests were periodically injected between the analyses of the extracts, to minimize errors.

The methodology consisted of putting $500 \mu \mathrm{L}$ of fortified fetalbovine serum ( $50 \mu \mathrm{g} \mathrm{L}^{-1}$ of chlorpyrifos, bifenthrin and $\lambda$-cyhalothrin, and $17.7 \mu \mathrm{g} \mathrm{L}^{-1}$ of deltamethrin) into $5 \mathrm{~mL}$ transparent glass vials. Then, $1000 \mu \mathrm{L}$ of water and $500 \mu \mathrm{L}$ of acetonitrile (ACN) were added to these samples, and the mixture was vortexed for $60 \mathrm{~s}$ at room temperature. Subsequently, it was cooled down in a freezer at $-20{ }^{\circ} \mathrm{C} \pm 2{ }^{\circ} \mathrm{C}$ for about $12 \mathrm{~h}$. After phase separation due to freezing of the aqueous phase (serum + water + proteins), approximately $100 \mu \mathrm{L}$ of acetonitrile was collected and analyzed by GC/ECD. Some samples were also evaluated by the GC-MS to confirm the results.

\section{Validation of the analytical method}

The extraction method (LLE/LTP/GC/ECD) was validated for the most significant figures of merit: selectivity, linearity, limits of detection and quantification, accuracy (recovery tests), and precision (both intra- and inter-day). The procedures were based on the recommendations by ANVISA. ${ }^{24}$

The selectivity was estimated by comparing the chromatograms obtained from fetal-bovine serum extracts and the human-blood serum extracts with those from the matrices fortified with $50 \mu \mathrm{g} \mathrm{L}^{-1}$ of chlorpyrifos, bifenthrin, and $\lambda$-cyhalothrin, and $100 \mu \mathrm{g} \mathrm{L}^{-1}$ of deltamethrin.
To build the calibration curve, prior to the application of the proposed method, the fetal-bovine serum samples were fortified at five levels $\left(20,35,50,75,90 \mu \mathrm{g} \mathrm{L}^{-1}\right.$, for chlorpyrifos, bifenthrin, and $\lambda$-cyhalothrin; $40,70,100,150,180 \mu \mathrm{g} \mathrm{L}^{-1}$, for deltamethrin), in triplicate. In this study, linearity was evaluated by the determination coefficient obtained from the linear regression of the calibration curve. The residue graphs of each pesticide were also used to verify trends in the distribution of errors in the different concentrations analyzed.

The limits of detection (LOD) and quantification (LOQ) were determined by multiplying by 3 and 10, respectively, the ratio between the standard deviation of the areas obtained for the blank extract triplicates and the analytical curve slope got from the fetal-bovine serum extracts.

The accuracy and precision of the method were evaluated in triplicates, by fortifying the fetal-bovine serum samples at three levels (20, 50, $90 \mu \mathrm{g} \mathrm{L}^{-1}$, for chlorpyrifos, bifenthrin and $\lambda$-cyhalothrin; $40,100,180 \mu \mathrm{g} \mathrm{L}^{-1}$, for deltamethrin). The accuracy was assessed by recovery assays (\%R), whereas the intra- and inter-day precision were investigated by estimating the coefficient of variation $(\% \mathrm{CV})$.

\section{Analysis of pesticide residues in blood-serum samples}

The miniaturized LLE/LTP/GC/ECD method proposed for pesticide analysis in blood-serum samples was validate and applied to blood-serum samples of rural workers from the city of Coimbra (Minas Gerais, Brazil) and individuals indirectly exposed to the pesticides (control). Both groups were formed by male individuals between 30 and 60 years old. The present work is part of a more extensive study entitled "Proteomic analysis and biochemical profile of the blood of rural workers exposed to pesticides", which was duly submitted to and approved by the Ethics Committee of the Federal University of Viçosa (CEP/UFV), under the protocol number 1052863.

The rural workers within the group of interest were involved in the planting and managing of a tomato crop by the moment the samples were collected. The study investigated eight blood-serum samples taken from them, and another two from the control group - the evaluations were done in duplicate. After being collected, the biological samples were labeled and appropriately stored in a freezer at $-80^{\circ} \mathrm{C}$, so that they could be used in another complementary related research.

\section{RESULTS AND DISCUSSION}

\section{Screening of critical conditions of the LLE/LTP/GC method}

The factors volume of added water, volume of extraction solvent, and stirring time were evaluated. Besides, the concentrations of each pesticide, as experimentally determined, were used as a response for building the Pareto Diagrams (Figure 1).

According to these diagrams, the stirring time did not significantly enhance the extraction of any of the pesticides. However, the tests vortexing for $60 \mathrm{~s}$ showed slightly better responses and, therefore, this was the duration chosen.

The volume of acetonitrile had a negative influence, while the amount of water positively affected the extraction of chlorpyrifos, bifenthrin, and $\lambda$-cyhalothrin. Thus, by diluting the sample and reducing the quantity of acetonitrile, it is possible to attain a higher percentage of analyte extraction. Probably, more acetonitrile and less water cause high precipitation of proteins, which can drag some fraction of the analytes together. Consequently, reducing the volume of acetonitrile minimizes protein precipitation, making the analytes more available for extraction.

On account of these findings, the conditions adopted for the method were $500 \mu \mathrm{L}$ of sample, $1000 \mu \mathrm{L}$ of water, $500 \mu \mathrm{L}$ of acetonitrile, and stirring time of $60 \mathrm{~s}$. 

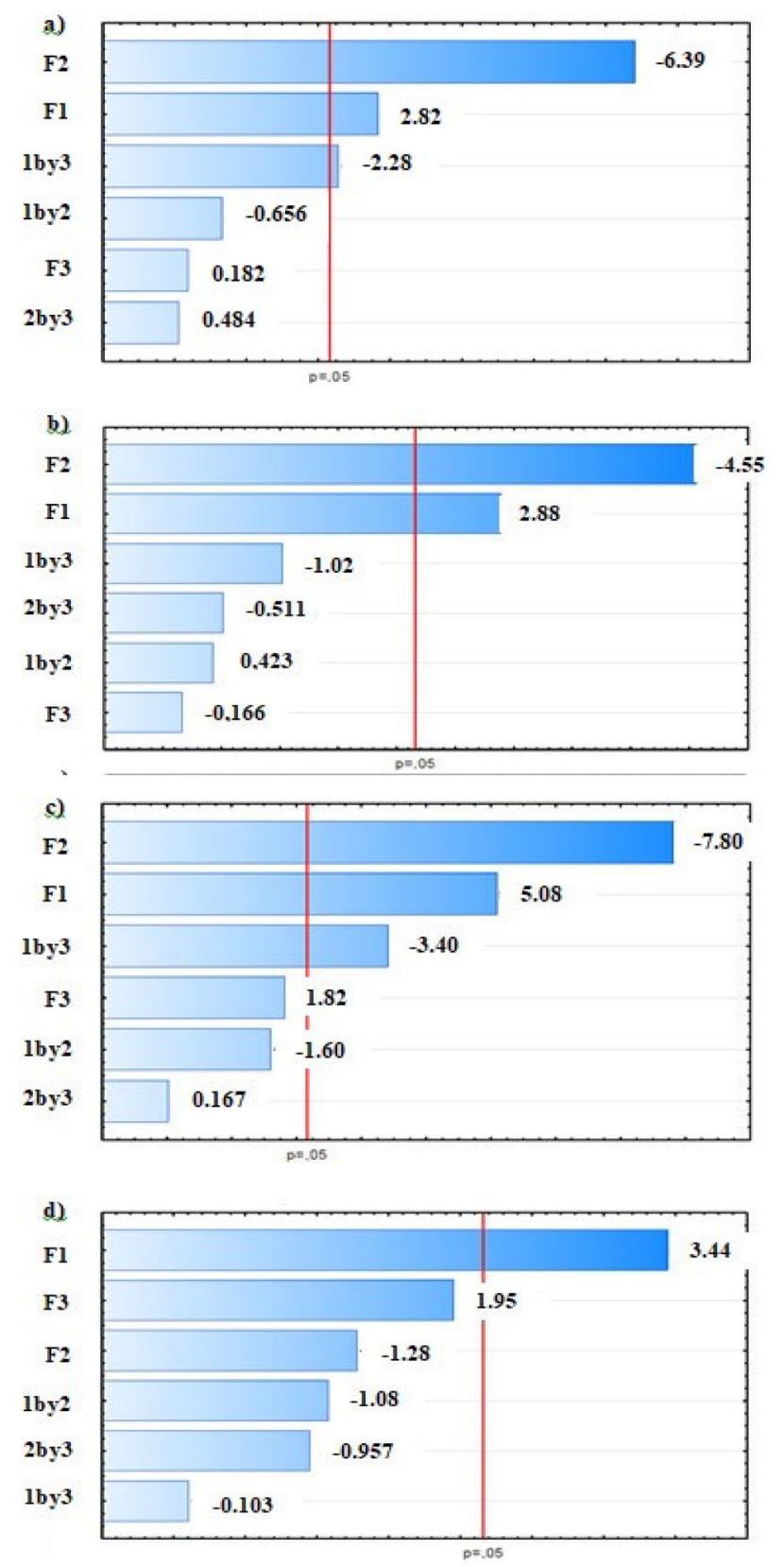

Figure 1. Pareto Diagrams of the effects of the factors volume of water $(F 1)$, volume of acetonitrile (F2), and stirring time (F3) on the extraction of the pesticides a) chlorpyrifos, b) bifenthrin, c) $\lambda$-cyhalothrin and d) deltamethrin from fetal-bovine serum

\section{Validation of the analytical method}

Figure 2 and Figure 1S present, respectively, the chromatograms obtained by GC/ECD from the extracts of samples of human-blood
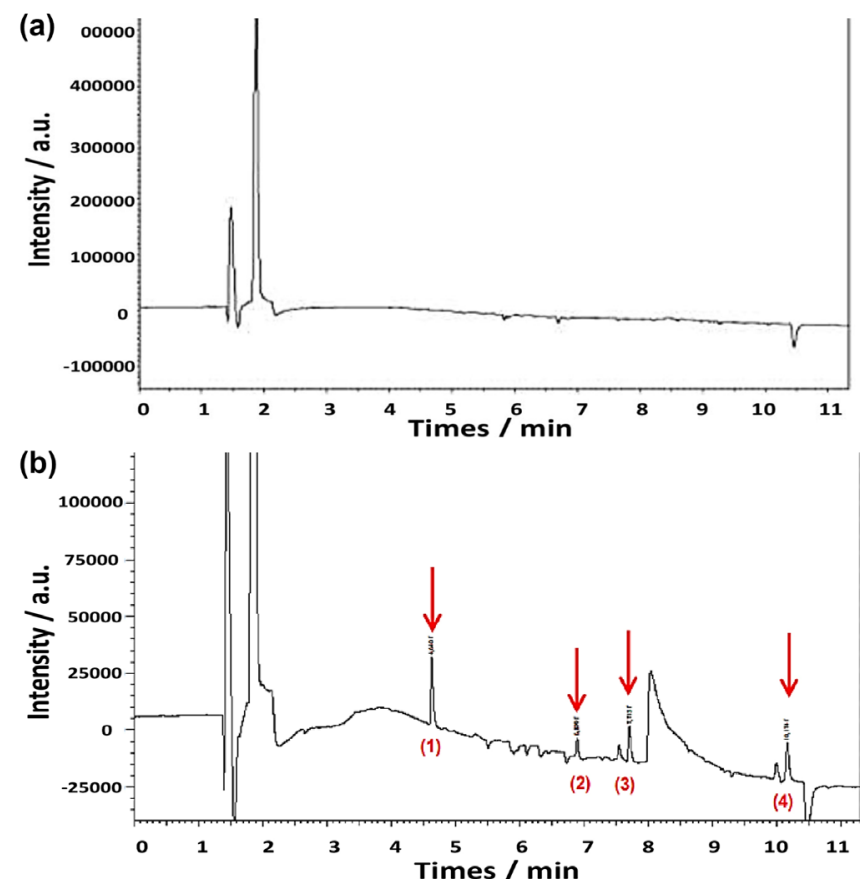

Figure 2. Chromatograms obtained by the GC/ECD. a) extract of analyte-free human-blood serum samples and b) extract of human-blood serum samples containing $50 \mu \mathrm{g} L^{-1}$ of chlorpyrifos, bifenthrin and $\lambda$-cyhalothrin, and $100 \mu \mathrm{g} L^{-1}$ of deltamethrin, obtained by the LLE/LTP method

serum, and from the extracts of samples of fetal-bovine serum, either pesticide-free or fortified with the pesticide standard solutions. Figure $2 \mathrm{~S}$ displays the equivalents chromatograms obtained by the GC-MS. There were no peaks at the retention time of the substances under study. This fact demonstrates the selectivity of the method and indicates that other compounds within these do not interfere in the analyses.

The values of the parameters of analytical merit for the proposed LLE/LTP/GC/ECD method were determined by using fetal-bovine serum samples fortified with the compounds of interest. They are presented in Tables 1 and 2 .

For all analytes, the coefficient of determination was higher than or equal to 0.990 , as recommended by ANVISA. ${ }^{24}$ Moreover, the residue graphs of the pesticides showed points randomly scattered but concentrated around zero. As the distribution exhibited a pattern, the variance could be deemed constant, and the relationship linear. This outcome attests that the chosen regression model provided a good fit to the data.

The LOD and LOQ values varied from 2.57 to $5.10 \mu \mathrm{g} \mathrm{L}^{-1}$ and 8.58 to $17.0 \mu \mathrm{g} \mathrm{L}^{-1}$, respectively. The limits found in this work were lower than those attained by Inoue et al. (2007) (250 to $\left.1000 \mu \mathrm{g} \mathrm{L}^{-1}\right),{ }^{25}$ who used the technique of protein precipitation in blood serum by LC-MS as the extraction method. On the other hand, Deerring et al. developed an LLE method for assessing

Table 1. Linear range, linear equation, coefficient of determination, and limits of detection (LOD) and quantification (LOQ) of the LLE/LTP method for each compound

\begin{tabular}{cccccc}
\hline Agrochemical & Linear range $/ \mu \mathrm{g} \mathrm{L}{ }^{-1}$ & Linear equation & $\begin{array}{c}\text { Coefficient of } \\
\text { determination }\left(\mathrm{R}^{2}\right)\end{array}$ & LOD / $\mu \mathrm{g} \mathrm{L}{ }^{-1}$ & $\mathrm{LOQ}^{\prime} \mu \mathrm{g} \mathrm{L}{ }^{-1}$ \\
\hline Chlorpyrifos & $20-100$ & $\mathrm{y}=2005.6 \mathrm{x}+15965$ & 0.990 & 2.57 & 8.58 \\
Bifenthrin & $20-100$ & $\mathrm{y}=589.3 \mathrm{x}+5922.2$ & 0.993 & 3.73 & 12.4 \\
$\lambda$-cyhalothrin & $20-100$ & $\mathrm{y}=1413.9 \mathrm{x}-7345.1$ & 0.990 & 3.10 & 17.0 \\
Deltamethrin & $40-200$ & $\mathrm{y}=1104.2 \mathrm{x}-26063$ & 0.990 & 3.26 & 10.9 \\
\hline
\end{tabular}


Table 2. Recovery rates $(\% \mathrm{R})$ and coefficients of variation $(\% \mathrm{CV})$ obtained from the analysis of fetal-bovine serum samples fortified at three concentrations

\begin{tabular}{|c|c|c|c|c|}
\hline Analytes & Nominal concentration $/ \mu \mathrm{g} \mathrm{L} \mathrm{L}^{-1}$ & $\begin{array}{c}\text { Accuracy } \\
\% \mathrm{R}\end{array}$ & $\begin{array}{c}\text { Intra-day precision } \\
\% \mathrm{CV}\end{array}$ & $\begin{array}{c}\text { Inter-day precision } \\
\% \mathrm{CV}\end{array}$ \\
\hline & 20 & $115 \pm 3.80$ & 3.32 & 12.1 \\
\hline \multirow[t]{3}{*}{ Chlorpyrifos } & 50 & $85.5 \pm 11.1$ & 12.9 & 11.0 \\
\hline & 90 & $87.3 \pm 9.5$ & 11.0 & 11.8 \\
\hline & 20 & $108 \pm 7.50$ & 6.93 & 11.0 \\
\hline \multirow[t]{3}{*}{ Bifenthrin } & 50 & $83.2 \pm 11.3$ & 13.6 & 14.8 \\
\hline & 90 & $85.9 \pm 6.89$ & 8.03 & 10.1 \\
\hline & 20 & $99.9 \pm 6.02$ & 6.02 & 12.0 \\
\hline \multirow[t]{3}{*}{$\lambda$-cyhalothrin } & 50 & $110 \pm 6.99$ & 6.36 & 14.5 \\
\hline & 90 & $83.6 \pm 4.82$ & 5.76 & 7.30 \\
\hline & 40 & $108 \pm 9.09$ & 8.42 & 14.8 \\
\hline \multirow[t]{2}{*}{ Deltamethrin } & 100 & $107 \pm 3.19$ & 2.98 & 15.1 \\
\hline & 180 & $89.9 \pm 12.6$ & 14.0 & 14.4 \\
\hline
\end{tabular}

organochlorines in human-blood serum, and they observed limits lower than those found in the present study. ${ }^{26}$ Their LOQ values ranged from 0.12 to $0.82 \mu \mathrm{g} \mathrm{L}^{-1}$, but the methodology they envisioned required volumes of samples and reagents larger than those used in current techniques, thus generating more residues. Also, the LLE/ LTP method performs both the extraction and cleanup in a single step, without the need for multiple extractions or pre-concentration of the substance of interest.

The accuracy and precision of the method were evaluated according to the recommendations of ANVISA. ${ }^{24}$ The results are shown in Table 2.

The recovery rates achieved in the majority of the experiments are within the acceptable range (70-120\%), according to ANVISA. ${ }^{27}$ Therefore, the method can be considered accurate. In general, as for both repeatability and intermediate precision, the coefficients of variation scored under $15 \%$, also complying with the recommendations. This fact attests that the method is accurate. ${ }^{28,29}$

\section{Analysis of pesticide residues in human blood-serum samples}

The developed method was used to detect pesticides in samples of human blood serum. The extracts were analyzed by both GC/ ECD and GC-MS.

When analyzing the extracts with the GC/ECD, a peak at the retention time of chlorpyrifos was verified in three of the samples. In two samples the level was below the limit of quantification. In the third sample extract, the concentration of the substance was high above the linear range of the method. Nonetheless, the analysis of extract via GC-MS and its comparison with the NIST database revealed that the peak corresponded to the drug phenobarbital, whose use by the volunteer had not been declared in the questionnaire. However, this demonstrates that this method can be applied for the determination of other compounds of interest in blood serum.

\section{CONCLUSIONS}

The proposed and validated LLE/LTP/GC/ECD method proved to be viable for analyzing the pesticides in blood-serum samples. It was withal effective, as it employes low volumes of sample and solvent, with the advantage of performing both extraction and cleanup in one single step.

On account of the results, the method developed can be considered capable of identifying and quantifying residues of chlorpyrifos, bifenthrin, $\lambda$-cyhalothrin, and deltamethrin in blood serum. However, the importance of knowing the history of the samples under analysis should be reinforced, so as to achieve a good performance of the technique. It is also highly important to adopt confirmation techniques to double-check the presence of the analyte of interest.

\section{SUPPLEMENTARY MATERIAL}

The chromatograms of the samples, and the physical-chemical and toxicological characteristics of the studied pesticides are freely available at http://quimicanova.sbq.org.br, in PDF format.

\section{ACKNOWLEDGEMENTS}

The authors would like to thank the Brazilian Agencies: Minas Gerais State Research Support Foundation (FAPEMIG), National Council for Scientific and Technological Development (CNPq) e Coordination for the Improvement of Higher Education Personnel Brazil (CAPES) for their financial support.

\section{REFERENCES}

1. Agência Nacional de Vigilância Sanitária (ANVISA), disponível em: https://www.gov.br/anvisa/pt-br/assuntos/agrotoxicos/programa-deanalise-de-residuos-em-alimentos/arquivos/3770json-file-1, accessed in March 2021.

2. Attaullah, M.; Yousuf, M. J.; Shaukat, S.; Anjum, S. I.; Ansari, M. J.; Buneri, I. D.; Tahir, M.; Amin, N.; Khan, S. U.; Saudi J. Biol. Sci. 2017, 25, 1284.

3. Koutros, S.; Harris, S. A.; Spinelli, J. J.; Blair, A.; Mclaughlin, J. R.; Zahm, S. H.; Kim, S.; Albert, P.S.; Kachuri, L.; Pahwa, M. Cantor, K. P. Weisenburger, D. D.; Pahwa, P.; Pardo, L. A.; Dosman, J. A.; Demers, P. A.; Freeman, L. E. B.; Environ. Int. 2019, 127, 199.

4. Brouwer, M.; Huss, A.; Van Der Mark, M.; Nijssen, P. C. G.; Mulleners, W. M.; Sas, A. M. G.; Van Laar, T.; De Snoo, G. R.; Kromhout, H.; Vermeulen, R. C.; Environ. Int. 2017, 107, 100.

5. Ntzani, E. E.; Ntritsos G. C. M.; Evangelou, E.; Tzoulaki, I.; EFSA Supporting Publications 2013, 10, 497.

6. Dhananjayan, V.; Ravichandran, B.; Curr. Opin. Environ. Sci. Health 2018, 4, 31 .

7. Achour, A.; Derouiche, A.; Barhoumi, B.; Kort, B.; Cherif, D.; Bouabdallah, S. Sakly, M.; Rhouma, K. B.; Touil, S. Driss, M. R.; Tebourbi, O.; Environ. Res. 2017, 156, 635. 
8. Lehmann, E.; Oltramare, C.; Dibié, J. J. N.; Konaté, Y.; De Alencastro, L. F.; Environ. Int. 2018, 111, 317.

9. Jokanović, M.; Toxicology. 2018, 410, 125.

10. Bordin, D. C. M; Monedeiro, F. F. da S.S; de Campos, E.G; Alves, M. N. R; Bueno, L. H. P.; de Martinis, B. S.; Sci. Chromatogr. 2015, 7, 125.

11. Souza, M. H. L.; Elias, D. O.; Fundamentos da Circulação Extracorpórea, $2^{\text {th }}$ ed., Centro Editorial Alfa Rio: Rio de Janeiro, 2006.

12. Sosan, M. B.; Akingbohungbe, A. E.; Ojo, I. A.; Durosinmi, M. A.; Chemosphere 2008, 72, 781.

13. Kim, M.; Song, N.R.; Hong, J.; Lee, J.; Pyo, H.; Chemosphere 2013, 92 , 279.

14. Sweeney, C.; Park, Y.; Kim, J. S.; J. Chromatogr. A 2019, 1603, 83.

15. Nováková, L.; Vlčková, H.; Anal. Chim. Acta, 2009. 656, 8.

16. Paterson, S.; Cordero, R.; Mcculloch, S.; Houldsworth, P.; Ann. Clin. Biochem. 2000, 37, 690.

17. Cazorla-Reyes, R., Fernández-Moreno, J. L., Romero-González, R., Frenich, A. G.; Vidal, J. L. M.; Talanta. 2011, 85, 183.

18. Buah-Kwofie, A.; Humphries, M. S.; J. Chromatogr. B 2019, 1105, 85.

19. Pozzebon, J. M.; Vilegas, W.; Jardim, I. C. S. F.; J. Chromatogr. A. 2003, 987, 375.

20. Myasein, F.; Kim, E.; Zhang, J.; Wu, H.; El-Shourbagy, T. A.; Anal. Chim. Acta 2009, 651, 112.

21. Magalhães, E. J.; Nascentes, C. C.; Augusti, R.; Queiroz, M. E. L. R. D.; Silva, J. C. C. D.; Afonso, R. J. D. C. F.; Am. J. Anal. Chem. 2012, 3,118 .
22. Gomes, R. P.; Sanson, A. L.; Lobo, F. A.; Afonso, R. J. C. F.; Coutrim, M. X.; Separations 2016, 3, 14.

23. Magalhães, E. J.; Queiroz, M. E. L. R.; Penido, M. L. O.; Paiva, M. A. R., Teodoro, J. A. R.; Augusti, R.; Nascentes, C. C.; J. Chromatogr. A 2013, 1309, 15.

24. Agência Nacional De Vigilância Sanitária (ANVISA), disponível em: https://www.in.gov.br/materia/-/asset_publisher/Kujrw0TZC2Mb/ content/id/19194581/do1-2017-07-25-resolucao-rdc-n-166-de-24-dejulho-de-2017-19194412, accessed in March 2021.

25. Inoue, S.; Saito, T.; Mase, H.; Suzuki, Y.; Takazawa, K.; Yamamoto, I.; Inokuchi, S.; J. Pharm. Biomed. Anal. 2007, 44, 258.

26. Deering, K.; Spiegel, E.; Quaisser, C.; Nowak, D.; Rakete, S.; Garí, M.; Bose-O'reilly, S.; Environ. Res. 2020, 184, 109271.

27. Agência Nacional De Vigilância Sanitária (ANVISA), disponível em: http://bvsms.saude.gov.br/bvs/saudelegis/anvisa/2003/ res0899_29_05_2003.html\#: :text=considerando\%20que\%20 a $\% 20$ mat $\%$ C3\% A 9ria\% 20foi, anal\% C3\% ADticos \% 20e $\% 20$ bioanal\%C3\%ADticos\%22\%20anexo\%20Art, accessed in March 2021.

28. Moein, M. M.; El Beqqali, A.; Abdel-Rehim, M.; J. Chromatogr. B 2017, 1043, 3.

29. Instituto Nacional de Metrologia, Normalização e Qualidade Industrial (INMETRO), disponível em: http://www.inmetro.gov.br/Sidoq/ Arquivos/CGCRE/DOQ/DOQ-CGCRE-8_07.pdf, accessed in March 2021. 